\title{
Socio-Economic Development Contributions of Cooperatives and Encountering Challenges in Ethiopia
}

\author{
Desalegn Fekadu Etefa \\ Ambo University: College of Business and Economics, Department of Cooperative Studies \\ PhD Candidate
}

\begin{abstract}
Cooperative is a useful instrument to alleviate the socio-economic problems of the societies in many countries in general and in developing countries in particular, including Ethiopia. Cooperation among people has existed since time immemorial. However, formal cooperatives began in Ethiopia since 1960. The objective of this study was to show the socio-economic development contributions of cooperatives and the challenges encountering the sector. Intensive conceptual and empirical literature reviews were made in the areas of cooperative development, cooperative policy and regulatory framework documents, and cooperatives periodic activity reports from the Cooperatives Commission of Ethiopia. The study indicated that the number of primary cooperatives has increased from 149 to 99,542 from 1960 to 2021 showing 66,000\% rate of growth. The number of members increased from approximately below one thousand to about 21 million during the same period demonstrating very high growth rate. Likewise, their capital was increased from about a million to 28.8 billion Ethiopian Birr during the stated periods. The finding identified challenges of cooperatives such as low participation and lack of awareness, low involvement of the stakeholders, lack of professionalism, weak linkage, inadequate support and lack of good governance. It necessitates provision of cooperatives education and training to promote members' participation, involving stakeholders, attracting professionals, creating strong linkages, solving capital related problems, promoting cooperatives' good governance and providing enabling legislation and regulation for the development of the cooperatives.
\end{abstract}

Keywords: Challenges; Modern Cooperatives; Primary Cooperatives; Stakeholders' Participation, SocioEconomic Contributions.

DOI: $10.7176 / \mathrm{JESD} / 13-1-04$

Publication date: January $31^{\text {st }} 2022$

\section{Introduction}

In the contemporary period, poverty is abolishing the lives of billions of the people around the world. As a result, many people sense in capable to change their lives. In this hardship situation, cooperative businesses emanated to be a strong, active, and feasible economic opportunity to alleviate poverty. The concept of human cooperation is not new; it existed even before the formation of modern cooperation. To overcome their immediate problems and to share their feelings, human beings traditionally work together in day to day life. As it is stated by Gary (1993), cooperative is an association of persons who have voluntarily joined together to achieve a common goal. They finance and operate the business for their mutual benefit. This implies they are created on the leading idea that by working together, a group of people can achieve an objective that would be unattainable if acting alone (Ruhul \& Mahin, 2014; Desalegn, 2019).

Evidence from various sources reveals that cooperatives are contributing to the country's economic and social development. For instance, report of International Cooperative Alliance (ICA) (2021) stated that about two billion people are involved in cooperatives, either as members or, as employees or both. The same source further indicated that nearly 280 million people get employment opportunities from cooperatives at global level. The livelihoods of almost half of the world's population are safeguarded by cooperative enterprises. This is particularly true in the rural areas where it provides an important potential for income generation and equity for the dwellers.

In order that cooperatives play their role, government's aid is highly required. Government supports cooperatives in creating enabling environment. These includeputting in place sound economic policy, technical, legal and administrative support to sector development, providing regulatory frameworks and transparent system; all of which together will create an environment conducive to sector development (United Nations Framework Convention on Climate Change (UNFCCC), 2014).

As modern business structure, cooperatives originated in Britain by Robert Owen in 1844 andit was introduced to Ethiopia by 1960 during imperial Hailesillasie regime. Successive governments, starting from the Imperial period to the Reformed governments in Ethiopia have given due attention to the role of coops and made deliberate effort to promote the same. However, the principles and approaches followed were obviously different, reflecting the political thinking and ideology of the regimes.

As indicated in the work of Kifle (2015a), the present government provided Proclamation No. 147/1998 and $402 / 2004$, which served as a legal framework. This declaration combined universally accepted principles of cooperatives. As a result of these; many cooperatives have been established in new forms in Ethiopia since 1998 
following the initiatives taken by the government.

For cooperatives principles to be fully implemented; there should be efficient policies to guide it. However, the process of policymaking in the country lacks the fundamental elements of the activities. Furthermore, the policy making in Ethiopia is not following a systematic and consultative procedure rather it is top down approach while a genuine bottom-up policy process is possible and preferable making (Teshome, 2007, cited in Kemal et al., 2018). This shows it is against the guiding principles especially in the case of cooperative sectors.

Consequently in line with these realities, this study was carried out to show the socio-economic development contributions of cooperatives and encountering challenges in Ethiopia. In doing so, the study tried to show the status of cooperatives in the Ethiopia, the gaps existing within the members and the government structures whose concern is on the sector, and ultimately briefs about the challenges encountering the sector as a result of the mentioned shortcomings and ultimately indicates the way forward to take coops out of the problems.

\section{Methods}

The methodological approach adopted in this review is "best evidence review" whose focus is targeted towards combining various systematic methods of study-selection and result exploration. The data were collected from various secondary sources such as, policy and regulatory framework documents, past study reports and cooperatives periodic activity reports, Federal Cooperative Proclamation No 147/1998 and Cooperative Societies (Amendment) Proclamation No. 402/2004. The most prominent secondary data were obtained from the Federal Cooperative Agency of the country. Moreover, primary data from the early findings of the researcher were taken. Based on their relevance, over very recent 30 related published journal articles, some newspaper articles, magazine articles and books were referred and used as a background to analyze and synthesize the existing conditions regarding the title. Depending on these, data were examined and interpretations were done to show the tendencies and status of cooperatives in Ethiopia. Basing the principles and values of cooperatives, the practical situation in the sector is examined and the problems encountering were identified. Eventually, the proposed interventions and strategies to be adopted are indicated.

\section{Emergence and Historical Development of Cooperatives \\ 4.1. Emergenceof Cooperatives at Global Level}

Cooperative has been the very basis of human history. Al mighty God, created the first man called Adam in his image and secondly created female for him not live alone (Genesis, 1:27). It was also true from the historical development of human beings that the primitive societies had labor divisions among family members. Accordingly, the males were engaged in hunting of wild animals while the female members were fruit and vegetation gatherers to feed themselves. This is a true indication that cooperative was there in the works of God and survival of human beings. The inter-dependent and the mutual help among human beings have been the basis of social life. It is the lesson of universal social history that man cannot live by himself and for himself alone. Since the beginning of human society, individuals have found advantage in working together and helping one another in all over the world. A cooperative operates for the benefit of its members. These member-owners share equally in the control of their cooperative. The members elect directors which, in turn, hire management to manage the day-to-day affairs of the cooperative in a way that serves the members' interests. It is based on the idea people working together for a common goal and common good (Dogarawa, 2005). This signifies cooperative is the basis for survival on the planet earth.

Many scholars argued that the origin of cooperative was in Europe (Holyoake, 1908; Shaffer, 1999). As modern business structure, it was startedin Britain in 1844 by Rochdale Societies who were termed as the pioneers of modern cooperative movement(Evans Lewis, 2006). They had the goal of social development. They commenced it being twenty-eight community members. They have endeavored to pooltheirresources together and finally formed the first consumer cooperative (Gibson, 2005, cited in Dogarawa, 2005). The founders also established a unique combination of written policies that governed the affairs of the cooperative. Based on its success, the Rochdale set of policies soon became a model for other cooperative endeavors, and became known as the general principles that make a cooperative unique from other business structures.

Following the success of the Rochdale Society, other types of cooperatives as textile plant and shoe factory were emerged between 1850 and 1855 throughout England. As a result, more than 400 cooperative associations taking Rochdale Society as a role model emerged in 1863 in British. Subsequently, the English movement grew steadily, becoming the prototypical for similar movements globally. Some of the European countries in which cooperatives way of life disseminated were France, Germany, Belgium, Austria, Italy, Denmark, Finland, Norway, and Sweden (Abell, 2004).

As cooperatives became an alternative of business throughout Europe, the body that has to play leadership role was highly required. Therefore, to take this responsibility, ICA was established in 1895. ICA is a nongovernmental organization who served as umbrella organization to promote friendly and economic relations between cooperative organizations of all types, at global level. This organization also hasan intention to promote 
and strengthen autonomous cooperative organizations throughout the world. In order to achieve this objective, branches of offices are opened in different parts of the countries. Finally, to accommodate the newly emerged types of cooperatives, the Rochdale principles were found to be amended. Accordingly, ICA adopted the revised statement in 1995 in its third meeting and came up with seven principles and ten values. These cooperative principles are guidelines by which cooperatives put their values into practice until today. On the other hand, cooperative values are general norms that cooperators, cooperative leaders and cooperative staff should share and which should determine their way of thinking and acting.

\subsection{Historical Development of Modern Cooperatives in Ethiopia}

Modern cooperatives movement introduced to Ethiopia in 1960. Of the ruling body existed in the country, main emphasis in this article review is given to the three regimes that have contributed to the cooperatives' development in Ethiopia, viz., Hailesillasie (1916-1974) Derge/military (1974-1991), EPRDF regime (1991 to 2018) and the Reformed Government (2018 to present) .

During the imperial Hailesillasie regime, cooperatives have got recognition by Decree No. 44 of 1960(FCA, 2005 cited in Bezabih, 2009). This decree had its own limitations then another newCooperativeSociety Proclamation No.241/1966 was to come to operative with concern of previous Decree's short comings. This enabled the cooperative society to realize their objectives. In its Five Year Development Plan, the Imperial regime envisioned an important role for coops in transforming small holding agriculture. Thus, the Farmer Workers Cooperative Decree No. 44 was provided the first legal framework, which was later replaced by the Cooperative Societies Proclamation No. 241/1966. This was relatively comprehensive and contained most of the essential contents of the legal framework. However, success was limited during the period due to several limitations with it (Mojo et al., 2015). It was also failed to be in line with the international cooperative principles and they were exclusive to farmers with larger farm sizes (Abate et al., 2014). Hence, they failed to survive in the succeeding regime.

In the reign of military regime, proclamation 1975 was ratified. This proclamation set condition for the nationalization of rural land and extra houses in urban areas on its article 10. Simultaneously, this decree provided for the creation of marketing and credit cooperatives by peasant association. After the overthrow of Emperor, Cooperative Societies proclamation No. 138 issuedin 1978. The intention of the military regime was to use coops as a key instrument to build a socialist economy. Thus, it pursued the cooperatives agenda more aggressively. The cooperatives were not autonomous organizations, but had purely political character. The approach followed combined force with extensive support including priority access to resources, goods and services. The number of coops and membership sizes were relatively large; butit was not viewed as a particular success for a number of reasons. Due to this reason, following the downfall of Derge regime, most of them disappeared rapidly. The number of primary cooperatives reached 10, 524 having 4,529,259 members started to decline following the decease of the Derge regime. The reason for their immediate disappearance is, by then, their property particularly cash was in the hands of the government structures. As a result, with the collapse of this structure, the properties of the coop societies were lost. Consequently, there was no distribution of assets between members. This created a lasting suspicion and distrust of cooperatives even until today. According to McCarthy (2001), it served as a vehicle to eliminate internal conflicts and also characterized by corruption and mismanagement.

It was in 1991 when the EPRDF came to power that Economic liberalization policies were first implemented in the country and also it was the time when cooperatives got chance to grow. However, much more attention to all sectors including coops was given by the reformed government that came to power from 2018. It was/is struggling for fair utilization of resources by the citizens (answering the question of equity and equality) though practical focus is not given by the concerned government sectors. The new policies have been effective in releasing the economy from rigid state control, but also mean that Ethiopian people have become exposed to the hazards of both domestic and international free market competition (Kodama, 2007). That means; they were facing challenges emanating from globalization, where the issue of competition and market pressure emerges (Cemal, 2019). Such issues are still affecting cooperatives of developing countries in general and Ethiopia in particular.

The government provided a new legal framework, which is entitled Proclamation No. 147/1998 and 402/2004 to promote cooperatives from 1991. The past experience, particularly the bad habit inherited in cooperatives during the Derg regime was highly hindering the development of cooperatives.In this regard, evidence shows that the numbers of primary cooperatives existing in Derge regime declined to 7,366 in 1991. Thus, the government had taken some years to build new mind-set up and to change the attitude of the community towards cooperatives (Holmberg, 2011). In connection to this, some "cooperative activists" and organizers assisted the government to reconsider the cooperatives positively. As Holmberg stated, ILO also played crucial roles in the renaissance of the cooperatives in Ethiopia, by organizing study tours for cooperative activists and leaders to strengthen their empathetic and leadership skills through sharing the experiences of the neighboring countries. Due to this, the government's opinion of cooperatives had rehabilitated and policymakers generally accepted the meanings and principles of cooperatives given by the ICA in 1995 (FCA, 2014). Consequently, these determinations led to the 
establishment of cooperative legislations that opened up a room for the flourishing of modern cooperatives in Ethiopia.

Succeeding this, new Legal Framework that guides the development of cooperatives enacted in the country. This legal framework is known as Proclamation No. 85/1994 was introduced to serve only agricultural cooperatives, with an aim to realize improved living situations to its members (Adugna, 2013). This proclamation states that "the government sets convenient conditions for the peasants living in rural areas to be organized freely and willingly to jointly solve their economic and social problems through pulling their resources." Contrary to the past two regimes, the new government opened a legal space to organize cooperatives voluntarily, democratically and within a market setting. Nevertheless this proclamation facilitated to rearrange farmers on a voluntary basis to establish new cooperatives or to reorganize and strengthen the old ones, the organizers had a hard time to change peoples' attitude towards cooperatives due to the bad image of the cooperatives of the Derg regime (Holmberg, 2011). Some measures taken shifted the minds of the members among which; sharing dividends after a year that in some way helped to encourage the use of the cooperatives.

Alike the past two regimes, the first cooperative society proclamation (No. 85/1994) was also only targeting the agricultural cooperatives and lacks sufficient details. As a result, the government enacted the second proclamation (No. 147/1998) in 1998. This proclamation outlined the layers of organizational structure of the cooperatives into primary cooperatives, unions, federations, and cooperative leagues that can foster broader growth of the movement (Kodama, 2007). The proclamation also specified related organs of the cooperatives that include members, a general assembly, a special resolution, and a management committee with clear roles and responsibilities.

As a matter of this new proclamation and amendment, cooperativesprinciple becameinclusive and universally accepted among societies. This has led to the appearance of some improvements in cooperative sectors, which in turn brought changes in the cooperative societies of the country. However, revision with this proclamation was undertaken with delay after 2016 , which is 18 years later. There is also limitation to implement this proclamation among all parts.

For instance, cooperative societies shall aim to solve social and economic problems by harmonizing their knowledge, wealth, and labor as stated by proclamation No.47/1998. The Federal government of Ethiopia established cooperative societies to bring all types of cooperative under one umbrella by proclamation No. 147/ 1998.Besides, the majority of the cooperatives have been initiated by the government, which shows its strong interest in cooperative movement, including cooperative governance which by itself raises the questions of cooperative independence.

Agricultural cooperatives were established and managed by government staffs, and membership was made compulsory. As a result, farmers failed to see the value and this perception was created in the cooperative institutions. Thus, cooperatives were without members' control, and finally the cooperative were captured by a small elite and middle class bureaucracy. They were also heavily dependent on government subsidies, instead of independence and self-reliant organizations in most developing countries (Hussi, 1993). Therefore, government interference is prevailing in the contemporary cooperatives being one of the cooperatives management issues in Ethiopia.

The government of Ethiopia has taken sympathetic actions in the history of cooperative movement after the year 1996. The measures include, organizing and reorganizing different types of agricultural cooperatives and establishing Cooperative Promotion Bureaus in regional states. At the Federal structure, the government has been established the cooperative promotion desk under the Prime Minister office. The Federal Cooperative Commission (currently Cooperative Commission of Ethiopia (CCE)), which is the highest government structure for cooperative promotionin the country was established in 2002 based on proclamation No. 274 / 2002. This Proclamation suits to the currently universally accepted ICA's cooperative principles; and the ILO's Promotion of cooperative Recommendation (2002) (No. 193). This infers the basic principles and values of the present day Ethiopian cooperatives are adopted from ICA. Nevertheless, the unanswerable issue is about the degree of implementation of the principles and realities on the ground among the non-educated members in particular.Moreover, to correct the short comings in the proclamation 147/1998; regulation number 106/2002 and amendment 402/2004 became an important instrumental document in the cooperative movement of the country (Addissie \& Dagnachew, 2009).

In general, since the commencement of modern cooperatives, Ethiopia has decreed four main new proclamations and an amendment act. These are Directive No.44/1960, Proclamation No.241/1966; Proclamation No.138/1978, Proclamation No. 85/1995, Proclamation No. 147/1998, and Amendment act No. 402/2004 (Bezabih, 2009). All these acts demonstrate that the federal and regional governments have recognized the contribution of cooperatives to economic and social development, food security and poverty reduction in Ethiopia.

As various researchers indicated, cooperatives are playing an increasingly important role in economic growth, poverty reduction and democratization in Ethiopia. The justification provided by Emana \& Nigussie (2011) presumed that through distributing agricultural inputs, providing improved technologies, and encouraging farmers to produce high value crops, cooperatives in Ethiopia have been creating immense socio-economic benefits to both 
members and outsiders. Cooperatives have also been paying higher prices to members and maintaining the price of floor for the commodities they market. The presence of cooperatives has by large created competitive markets and protected the producers, and even benefited non-member farmers (Emana \& Nigussie, 2011).

In serving as a market channel, cooperatives are also involved in output marketing and creating market opportunities. In doing so, they are achieving good results in the areas of coffee, sesame, grains, animal products, milk and milk products which they have effectively marketed.

The direct and indirect employment opportunities created for many individuals is also the other important economic benefits of cooperatives. As evidence indicated in CCE (2021), to above 1,987,379 employment opportunities were created by cooperatives in Ethiopia.

In addition to the primary cooperatives, cooperative unions have also been engaged in product processing and value addition, thereby economically benefiting their members. Currently, in a situation where the country is facing both political and economic war, cooperatives are used as a tool to overcome the shortage of foreign currencies by supporting the production and export of high value commercial crops, such as coffee, sesame, grains, fruits \& vegetables, animal products, milk \& milk products, coops are earning significant amount of foreign currency. Report from the Oromia Cooperatives Agency (OCA) shows that in 2020, Coops in Oromia region earned about 50 million USD from exporting the stated productions. This infers cooperatives have been playing important roles in economic benefits, ensuring a fair share of resources, and reducing income disparity.

The economic benefits of cooperatives discussed earlier have also their share in contributing to social benefits, as the income earned from cooperatives could be invested in children's education and cover health expenses. Furthermore, as service provision being one of the objectives of cooperatives, both primary cooperatives and cooperative unions should spend about $5 \%$ of their profits as investment in social services (EPRDF, 1998, cited in Mojo et.al, 2017). This has also long-term economic benefits to the cooperatives, since it can help to increase the social capital of the community. Some empirical studies also indicate that cooperatives have significantly positive impact in creating social and human capital (ibid).

In this regard, specific evidence provided by Emana \& Nigussie (2011), indicated that cooperatives also perform a wide range of social activities. They contribute to the development of community health by providing training on family planning, HIV prevention, and on personal and environmental hygiene. They also involve in building public infrastructure, such as health centers, clean water, schools, roads, bridges, etc. They support also the youth, children and women, the homeless and disabled individuals and ensure their participation in the economy. The sectors also take part in awareness creation, provision of good social protection for employees and in creating a joint voicing mechanism for the rural and scattered people.

Besides the modern form of cooperatives, "Idir, Iqub and Debo", which are traditional, form of cooperatives, are contributing in the social and economic aspects of the communities. The main services provided by these mutual organizations are traditional insurance, or a safety net, typically for paying funerals, contributing money and giving for the winner of the lottery in turn to solve financial problem and mobilizing labor to collect crops or constructing houses etc. respectively. In general, people traditionally operate using resources pooled by members on a regular basis. In spite of their potentials, only a few cooperative unions are currently undertaking such activities of contributing to the social wellbeing.

In summary, cooperatives have contributed a lot in the country's socio-economic development in supporting both the members \& non-members of the country's community by providing different products, services, as well as variety of benefits such as securing their food, increasing their income, improving life style \& social participation, \& inputs for their agriculture activities.

Even though wider areas where cooperatives touch in the life of Ethiopian people were mentioned, yet the contribution of cooperatives to the national GDP is much less. Thus, this needs the cooperation of all including the government to make the sector contribute significant share to the country's GDP.

Contrary to its multi socio-economic benefits mentioned so far, as some studies indicate, cooperatives have been negatively contributing to environmental sustainability in Ethiopia (Mojo et al., 2015b). The authors stated that the better prices farmers got from cooperatives motivated the farmers to further increase their yields through intensifying production impacting the forestlands and consequently utilizing the natural resource unwisely. As to the recommendations of scholars, cooperatives should be environmentally sustainable as they are economically viable and socially equitable, as long as they are guided by principles of the International Cooperative Alliance. They are also expected to provide financial and material support for environmental protection, soil and water conservation, forest, wildlife, water and air protection activities.

However, in Ethiopia, in the policy formulation process, few government officials on the top are the key actors, whereas the people and other stakeholders have limited participation in the process. In this regard, the study conducted by Alemu (2015) proposed that for the process of policymaking, the responsible bodies should not only politicians, but also representatives of the people, experts and scholars. Moreover, the finding of Kemal et al (2018) shows most policies that guide the existing systems are emanating from executives. There is also limited legislative branch role, and other policy actors at both federal and regional levels. 


\section{Tendencies and Status of Modern Cooperatives in Ethiopia}

In spite of the defects mentioned so far, cooperatives became a path to socio-economic and social empowerment in Ethiopia. Various findings including ICA verified that the worth of cooperatives to Ethiopian societies is radically growing with the newly institutional reform in cooperatives since 1991. The plan of the government was forming at least one primary cooperative in each village and concurrently one union per district. This enhanced the development of cooperatives in Ethiopia (Emana, 2012). Subsequently, between 2006 and 2021, there was more than $378 \%$ increment of number of cooperatives in the country (Figure 1).

Currently, the numbers of primary cooperatives and cooperative unions are raised to 99,542 and 395 respectively. Of these, the number of primary cooperatives and cooperative unions in Oromia accounts to 22,613 and 121 respectively. The same report from CCE (2021) indicated that the capital of primary cooperatives in particular is elevated to birr 28.8 billion Ethiopian birr where that of Oromia region reached 10.4 billion. Similarly, currently the members are grown from 3,642,602 in 2006 to 21,043,370 in 2021. The member of primary cooperatives in Oromia is $11,545,092$ as of 2021 . The rate of growth of number of primary cooperatives and the number of members is $387 \%$ and $478 \%$ respectively from 2006 to the date of this evaluation report. This infers the longitudinal analysis of the number of cooperatives demonstrates growing trend over time.

Figure 1: Trends and Status of Primary Cooperatives from 2006 to 2021

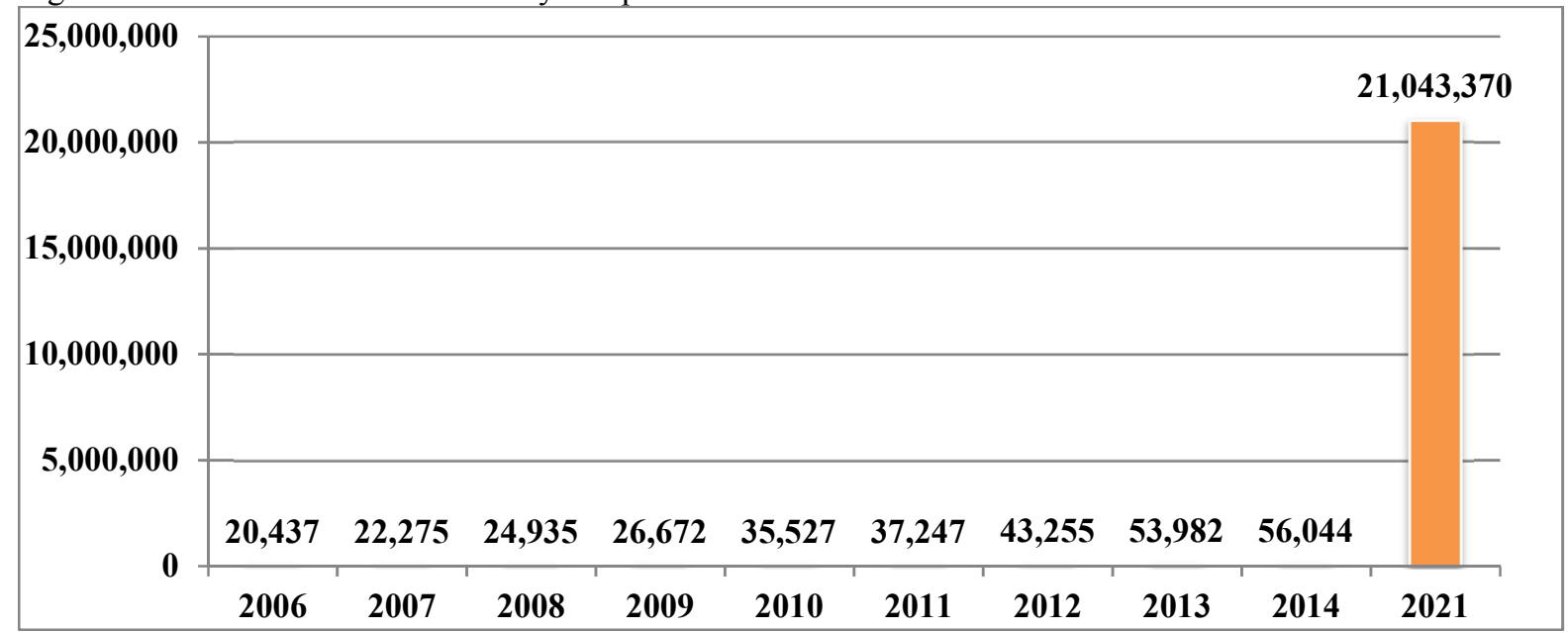

Source: FCA, 2021

Concrete evidence obtained from FCA for nine consecutive periods, confirms the trends and status of cooperatives in Ethiopia has shown paradigm shift (Figure, 1).

Moreover, to analyze the trends of the primary cooperatives, rate of growth for the periods from 2006 to 2014 is computed, which can be seen from Figure 2. Accordingly, the computation reveals that the highest growth rate is recorded in the history of number of primary cooperatives during 2009-2010, which is $33.2 \%$. Another significant increase was during $2012-2013$, when it was raised by $24.8 \%$. This was the time when both the Federal and regional governments have focused on cooperative movement and cooperatives have been considered as an instrument to reduce poverty and create employment. The government has formulated and implemented many strategies and programs like Agricultural Development Led Industrialization, Sustainable Development and Poverty Reduction Program, Plan for Accelerated and Sustained Development to End Poverty (PASDEP) and Growth and Transformation Plan.

On the other hand, the lowest growth rate was observed during 2013-2014 and 2010-2011. In these periods, only $3.8 \%$ and $4.8 \%$ were registered respectively. In general, apart from the differences observed, the number of primary cooperatives increased year by year. This shows growing number of primary cooperatives in Ethiopia. 
Figure 2: Growth Rates of Primary Cooperatives from 2006-2021

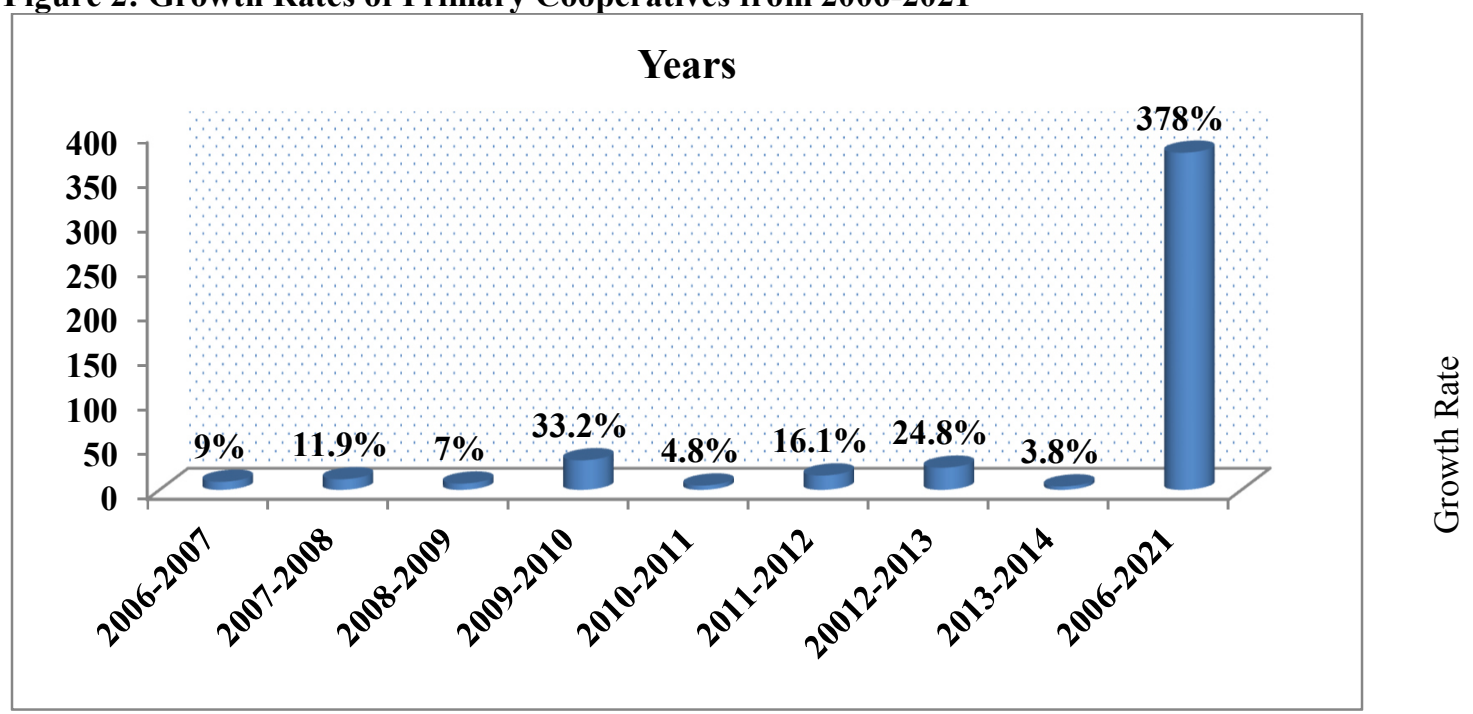

Source: Computed from FCA, 2021

However, there is still lack of working capital among the majorities of cooperative members (Mohammed, 2015). For instance, data provided on SACCOs by Kifle (2015b) signifies, of the 14,453 SACCOs operating in the country, their impact to the national finance is less than one percent, and many struggle with low capacity management and governance.

\subsection{Analyzing the Trends and Status of Cooperatives by Geographical Distribution}

The total number of primary cooperatives of all regional states at the end of 2021 being about 99,542 with about $21,043,370$ individual members. More than 2.2 million (24\%) of the cooperative members were also women, the number showing an increasing trend. Oromia region represents the largest primary cooperatives with 11,545,092 (54.9\%), followed by Addis Ababa with 12,130 (21.6\%), SNNPR with 11,702 (20.9\%), Amhara with 7,412 (13.3\%) and Tigray with $4,539(8.1 \%)$. The number of primary cooperatives in the rest of the regions is low, which is collectively $3,842(6.9 \%)$.

In terms of number of membership, again Oromia region constitutes the largest number of members (32.9\%), followed by Amhara (31\%), SNNPR (15.5\%) and Addis Ababa (10.3\%) as it is placed in sequence in table 1.

On the other hand, in terms of capital, Addis Ababa is the largest covering $57.3 \%$ of the total capital of the country's primary cooperatives. This is followed by Oromia region, which covers $36.1 \%$ of the national primary cooperatives 'capital. Except Addis Ababa, all the regions together cover less than $50 \%$ of the national capital of primary cooperatives. This implies most of the primary cooperatives residing in the rural areas are suffering from lack of working capital. Due to this, most primary cooperatives could not be engaged in big business and also cannot afford for the infrastructural facilities needed for them. As the circulation of blood is necessary for maintaining life in human body, in the same way, finance is the life blood of cooperatives (Ramachandran \& Srinivasan, 2010). This indicates the government has to device mechanisms of enhancing their financial capabilities including establishing national cooperative bank.

To sum up, during the period of 2006 to 2021, the number of primary cooperatives, the number of members and the capital of the members shown rapid growth over time. As indicated in (figure 1), the cumulative membership has increased from 3.6 million to above 21 million over the same period representing over double proliferation (accounts $478 \%$ ). The capital of the society has also shown an increase of $500 \%$ over the same period. In general, as far as the trend is concerned, it can be realized that cooperatives have been increasing in terms of number of primary cooperatives, members and capital in all regional states of the country over time. Apart from their growing number of members, as various researches indicate, they are not well informed about the basic cooperative principles and values and create the inspiration among members and about their rights and duties in their organization.

\subsection{Analysis in terms of the Trend and Status of Secondary Cooperatives (Cooperative Unions)}

This comparison is done by taking the data of 2014 since the recent one is incomplete to put by regions. In this case, the data is offered to show the numbers of cooperatives in each region and the capital they hoarded. As of 2021, according to FCA, there were 395 cooperative unions in 6 regional states including Addis Ababa and Dire Dawa city administration, where that Oromia region constitutes 121 . Their capital was 2.3 billion.

Due to the absence of sufficient and reliable information from FCA, data of cooperative unions from Afar, 
Gambella and Somale regions is not incorporated for the analysis, hence the decision about the rends of cooperative unions is based on the eight regions listed in table 2. On the other hand, it is also difficult to analyze the detailed financial performance indicators.

Accordingly, Oromia region holds the largest numbers of cooperative unions and capital, which is $38.6 \%$ and $52.4 \%$ respectively. This is tracked by SNNPR, where $19.6 \%$ of the country's cooperative unions are found and followed by Amhara region which constitutes 17.4\% of cooperative unions. On the other hand, Amhara region is the second in terms of capital of unions which accounts to $32.5 \%$ next toOromia regional state.

\section{Challenges of Cooperatives}

In spite of the some progress mentioned above, cooperative movement during the last 60 years of its existence is not inspiring. Empirical evidence reveals that the cooperative movement in Ethiopia is facing several challenges. This sector is reliant on government for various reasons. There are also continuous government interferences, governance issues, accountability, legislative and policy support and new product development. In general, these challenges can be categorized into internal and external challenges:

Internal challenges are problems emanating from the coops (primary up to federation level) members, managers, managements and Board members etc.

External challenges are challenges belonging to government structures (structures established to support coops sector) and other stakeholders. Anyways, the major challenges are the following:

\section{Low participation of members and lack of awareness}

Members do not take part in regular meeting of their cooperatives including voting their leaders. This is the most major problem of cooperatives in Ethiopia. Poverty and illiteracy are among the major factors for members not to attend regular meetings of the society. As they do not know to write and to read, they feel shy to attend the meetings (Nakkiran, 2002). This happens due to members' lack of awareness, and training on cooperatives related issues, most of the cooperative members are not participating actively in decision making, planning and implementation of business activities of the cooperative. Most of the primary cooperatives have been established without organizing proper cooperative education programs to create sufficient knowledge and skills on cooperative aspects.

Moreover, people are not well informed about the objective of the movement, the contributions it can make in rebuilding the society and the rules and regulations of cooperative institutions. People look upon these institutions as means for obtaining facilities and concessions from the government. This hinders the application of cooperative principle 'democratic member control'. In short, the source of all challenges is members' failure to know their rights and duties and act accordingly has paved the way for other challenges.

\section{Lack of Good Governance}

Accountability and transparency, which are important principles of governance, are ratified by existence of effective cooperative governance. It was found that most of the Internal Audit Committees of cooperative in Ethiopia that have been appointed by the members failed to exercise their duties, functions and responsibilities. Likewise, members usually have more tendency of appointing prominent members to hold board position in their cooperatives. This will result in board members failure in execution oftheir duties according to the best governance practices. This in turn leads to mismanagement of the resources of the cooperatives, which has led to the death of most cooperatives at their infancy stage.

\section{Lack of Professionalism}

This is related to the cooperatives' management committee members who have no knowledge of cooperative business transaction. In most cases, cooperatives are unable to employ capable management staff and the burden of due diligence is left to cooperative members who may have limited education on financial management. These committee members also lack essential capability to exercise manage the cooperatives.

\section{Inadequate Support and Weak Regulation and Supervision}

The capacity of FCA and regional cooperative promotion agency to effectively promote, regulate and supervise cooperatives is not in a position. This is resulted from absence of separate specialized units at the federal and regionalstates. The FCA is accountable to the Ministry of Trade which has no much concern with cooperatives and Regional Cooperative Agencies are accountable to the Agricultural Offices. Due to this, there is lack of strong coordination to solve the problems of cooperatives such as promoting, supervising and regulating different type of cooperatives; and limited mobility of staff due to shortage of logistics. The problem is complex at woreda level.

\section{Weak Linkage of Cooperatives with Stakeholders}

There is no strong relation between FCA and different stakeholders, particularly with the research institutes. Learning and improvement in technical capability does not take place in isolation but in interaction with support 
institutions. There is need for policy-maker and policy analysts in Ethiopia to think more to relate their policies into the wider national system (UN, 2002). Practical evidence shows that the federal and regional governments' power relation, the absence of institutionalization and coordination are among the challenges that have impact on the integrated regional development policy formulation and even implementation (Kemal et al., 2018). As to Oqubay (2015), some policy instruments were not entirely based on research.

\section{Low Stakeholders' Participation particularly in Policy Formulation Process}

There was less room of participation for the people and other stakeholders in the policy formulation process in Ethiopia (Kemalet al. (2018). Most people knew nothing about the processes involved in formulating policies; only those who had participated in the process as committee members or by attending workshops seemed to have an idea of what was involved (Worku, 2000). The political roles and ideology of the ruling party shaped the policymaking process, in which its ideas and interests prevailed and intertwined with the policies and structures of government both at federal and regional levels. In principle, however, in the process of policymaking the responsible bodies are not only politicians, but also representatives of the people, experts and scholars, especially in today's 'administrative state' era, with the rapid expansion of government functions and the extensive use of administrative discretion, administrative authorities are involved in public policy initiative growing (as cited in Huang, 2002).

\section{Lack of Adequate Infrastructure}

Farmers in developing countries, including Ethiopia face a number of problems in marketing. Constraint of physical condition such as insufficient means of transportation, bad roads, energy, agricultural product processing equipment, bank and etc. are there. Due to this, there is lack of storage facilities prevents the farmers from storing their farm produce until the season when the prices rise. This results in loss of income of the small scale farmers. Besides, farmers have very small bargaining power. Absence of reliable and up to date market information and also lack of market linkage to sell their products is highly challenging the sectors. As a result, they are forced to sell their product at low price in local area.

\section{Globalization}

As cooperatives are attaining opportunities from globalization, at the same time, most cooperatives in developing countries including Ethiopia are encountering challenges from globalization. This occurs from inability to compete typically evolving from lack of capacities.

Figure 2: The General Challenges Identified from case Study, 2019.

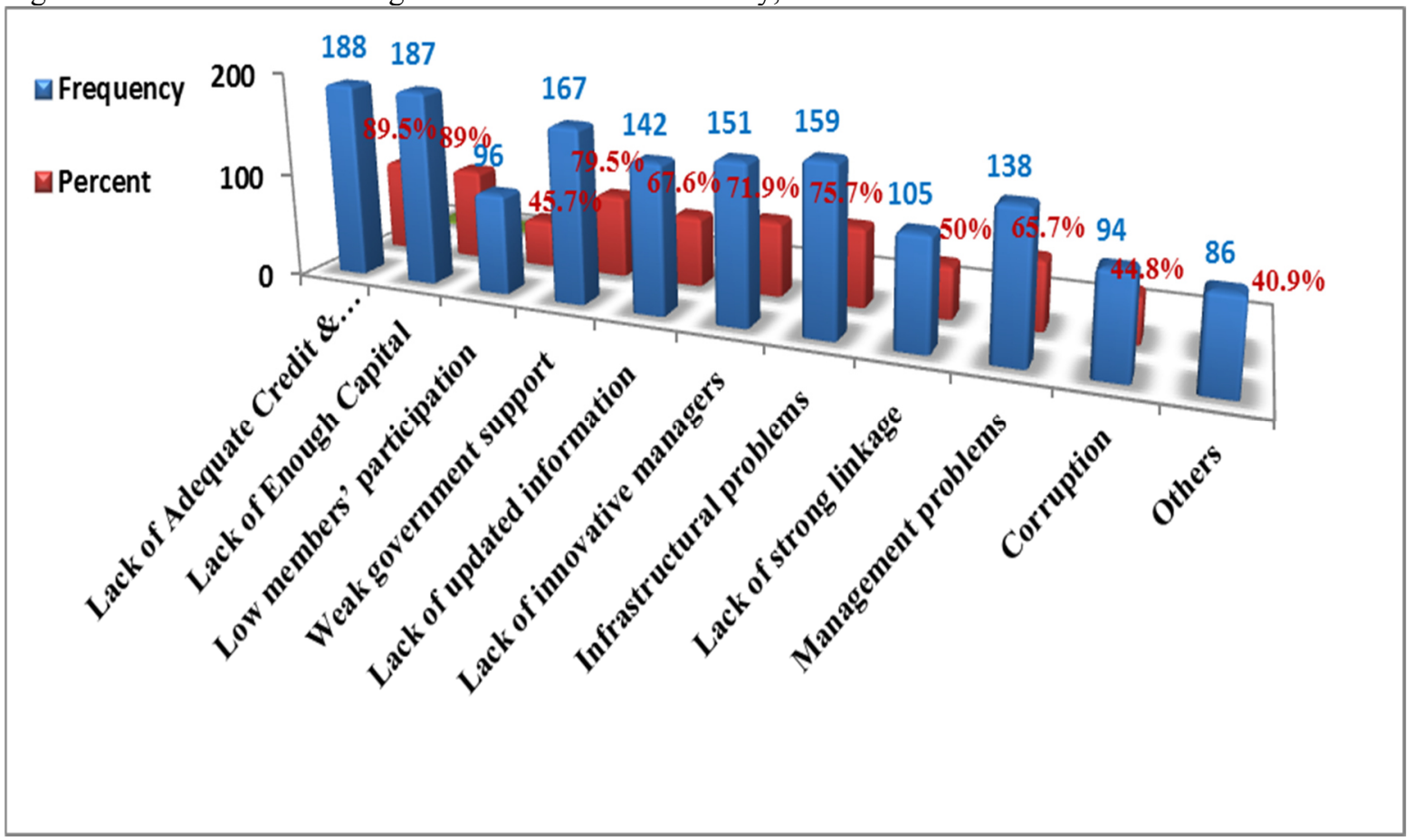

Source: Researcher's Computation, 2019 from Lalo-Assabi Multi-purpose Cooperatives 


\section{Conclusion and Proposed Interventions}

\subsection{Conclusion}

Cooperatives play a major role in socio-economic development. Cooperatives are also seen as vehicles for the injection of government development strategies to the local level. The trends and status of cooperatives in Ethiopia has shown rapid growth over time.In spite of the elevated numbers and members of primary cooperatives, their capital is still low. As a result, their contribution to the national GDP is low. Though, modern cooperatives have rapidly increased and contributed to community advancement, but numerous challenges are still there being embedded in the economic, social, institutional, political and environmental settings. In general, cooperative movement during the last 60 years of its existence is not inspiring when compared is an expected achievements. There are problems identified within and out of the cooperatives, which needs the contribution of the concerned bodies to alleviate the problems.

\subsection{Proposed Interventions}

Based on literatures reviewed, actions that can be taken by governments at different levels to strengthen cooperatives and for the sector growth in general are identified. Accordingly, actions that have to be taken by all stakeholders are:

\section{Active Involvement of Members}

$\rightarrow$ There should be active involvement of members on their fate.

\& The members must be alert and they must elect right persons to the board.

\& They must attend the meetings regularly and must bring the policies to the task.

$\leftrightarrow$ - They should pay attention to member mobilization

or The members should be loyal and committed to struggle wrong doings.

$\leftrightarrow$ Mobilize resources through various means and wisely utilizing resources they hold.

$\approx \rightarrow$ Motivating employees in order to reduce frequent turnover

\& Not to go against own Coop: Being standing in accordance to own organization helps to reach an intended destination, which is indicated in the saying "United we stand, divided we fall". This argument is justified by $6^{\text {th }}$ values of coops.

\section{Providing Cooperatives Education and Training}

or Most of the cooperative members are in lack of awareness on cooperative activities, legal aspects, and cooperative business. Therefore, there is a need to strengthen the cooperative training institutions to undertake demand based training programs and continue cooperative education to cooperative members, managers and other concerned officials.

\section{Providing Enabling Legislation and Regulation}

$\rightarrow$ For coops to function appropriately; there is a need of creating an enabling work environment. Thus, laws governing coops should be constantly revised to go with changes. It was in 1998 that the first proclamation was enacted and revised 18 years later in 2016. There were so many changes and hence so many problems coops were facing in between these intervals.

$\approx$ The government needs to ensure a legislative and policy environment that permits coops to be competitive by facilitating coop ability to purchase subsidiary businesses, enter joint ventures, trade and invest across national boundaries and amalgamate or otherwise merge their activities in whole or part with other coops.

or Promoting good governance that creates peaceful co-existence, a sound political linkage and coordination among different governmental levels and administrative sectors in the country.

\section{Providing Cooperative Policy}

or Since its establishments, cooperative is function without its own policy. Policy shows indicates the overall direction of any activities. So, there is a need to prepare National Cooperative Policy.

\section{Creating Strong Linkage between Coops and Others}

or There should be a strong linkage between governing sector, coop structures and others particularly with Universities and other higher institutions existing in the country.

\section{Attracting Devoted Professionals}

or At different tiers of coop structures, the sector lacks appropriate leaders. In most cases coops are led by management staff and the burden of due diligence is left to coop members who may have limited education on financial management. On the one way, this sector lacks professionals and on the other way there is frequent turnover. 
Solving Capital Related Problems of Coops

or The main capital source of coops is member`s share capital. However, the current situation clearly shows that coop is not in a position to collect sufficient capital from their members.

\& $\rightarrow$ Moreover, coops are not in a position to get a credit from financial institutions due to collateral problems.

\&- So, more enabling condition has to be arranged to solve problems in this regard by encouraging financial institutions like Coop Bank of Oromia.

\section{References}

Abate, G. T., Francesconi, G. N., \& Getnet, K. (2014). Impact of Agricultural Cooperatives on Small holders' Technical Efficiency: Empirical Evidence from Ethiopia. Annals of Public and Cooperative Economics, 85(2), 257-286

Abell, P. (2004). Cooperative Movement, Encyclopedia Encarta 2004 Edition.

AddissieShiferaw \& DagnachewAsrat (2009). Law of Public Enterprises and Cooperatives: Justice and Legal System: Research Institute, Addis Ababa, pp. 1-197.

Adeler, M. J. (2009). Enabling Policy Environments for Co-operative Development: Institute of Urban Studies, University of Winnipeg.

Adugna, H. (2013). Co-operative Approach to Community Livelihood Improvement: The Case of Ada'a District, Oromia Regional State, Ethiopia: International Journal of Development and Sustainability,Vol. 2, No. 3 (2013), pp. 2124-2145.

Alemu, T. (2015). Policymaking Practice and Challenges of House of Peoples Representatives (HoPRs): Sky Journal of Agricultural Research, 4(7), pp.132-146.

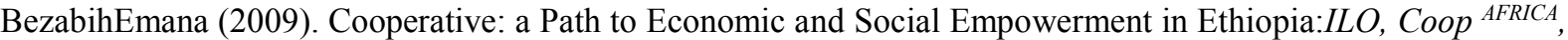
Working Paper No.9,pp. 9-14,Dare Salam.

Birchall, J. (1997). The international Co-operative Movement. Manchester, UK: Manchester University Press.

Cemal Karakas (2019). Cooperatives: Characteristics, Activities, Status, Challenges: European Parliamentary Research Service (EPRS).

David, J. (2008). Mobilizing Rural Institutions for Sustainable Livelihoods and Equitable Development; International Food Policy Research Institute, Addis Ababa Ethiopia.

Dogarawa, A. Bello (2005). The Role of Cooperative Societies in Economic Development:Journal of the Department of Public Administration, No. 23161, pp.1-20, Ahmadu Bello University, Zaria-Nigeria, retrieved from: http://mpra.ub.uni-muenchen.de/23161/.

Desalegn Fekadu (2019). The Role of Multi-Purpose Cooperatives in the Economic Development in Ethiopia, the Case of Lalo-Assabi District (West Wollega Zone, Oromia Regional State).Research on Humanities and Social Sciences. Vol.9, No.21, pp 13-30.

Emana, B. \& M. Nigussie (2011). Strategizing Cooperative Development in Ethiopia: anunpublished Report Submitted to Agricultural Transformation Agency (ATA). Addis Ababa, Ethiopia.

Emana, B.\&M. Nigussie (2012). Cooperative Movement in Ethiopia, a Paper Presented at Workshop on Perspectives for Cooperatives in Eastern Africa, Uganda: Kampala.

Evans Lewis, M. R. (2006). The Role and Significance of Cooperatives in New Zealand Agriculture: $A$ Comparative Institutional Analysis.

Federal Cooperative Agency (2009). Status of Cooperatives in Ethiopia: (Unpublished) Addis Ababa

Federal Cooperative Agency (2010). Cooperative Annual Magazine: Addis Ababa, Ethiopia.

Federal Cooperative Agency (2014a). Cooperatives. Annual publication 1(11), Addis Ababa: FCA.

Federal Cooperative Agency (2014b). Unpublished data, Addis Ababa, Ethiopia.

Federal Cooperative Agency (2014). Federal cooperatives Agency, Annual Publication, Vol1, No11

Gary, B. Hansen (ILO COOP) (1993). The role of cooperatives in the promotion of employment and income: Presentation to the Meeting of Experts on Cooperatives, ILO in Geneva Switzerland, No. 3 (1993), pp.8-16, retrieved from: https://aas.org.

Holmberg, Susan Ruth (2011). "Solving the Coffee Paradox": Understanding Ethiopia's Coffee Cooperatives through Elinor Ostrom's Theory of the Commons. Open Access Dissertation, PhD. 379.

Holyoake, G.J. (1908). The History of Cooperation, London UK: T. Fisher Unwin.

Huang, R. (2002). On the Nature of Public Policy. Beijing: Peking University, Beijing Chinese Public Administration Review.

International Cooperative Alliance (ICA) and International Labor Organization (ILO) (2014). "Cooperatives and the Sustainable Development Goals: A Contribution to Post 2015 Development Debate.” A Policy Brief, Geneva.

ICA (2019, July 6). Coops for Decent Work: International Day of Cooperatives Theme. A Policy Brief, Geneva, retrieved from: www.ica.coop.

Kemal Abdela Kaso, Sukanya Aimimtham, Sukhumvit Saiyasopon \& WeerakulChaiphar (2018). Integrated 
Regional Development Policy Formulation in Ethiopia: Journal of Politics and Law; Vol. 11, No. 4 (2018); pp. 153-163, 2018 ISSN 1913- 9047, E-ISSN 1913-9055, Published by Canadian Center of Science and Education.

Kenichi Ohno (2009). Ethiopia: Political Regime and Development Policies, Graduate Institute for Policy Studies (GRIPS), Tokyo.

KifleTesfamariam (2015a). Cooperative Movement in Ethiopia: Development, Challenges and Proposed Intervention:Journal of Economics and Sustainable Development, Vol.6, No.5 (2015), pp. 38-45, retrieved from www.iiste.org, ISSN 2222-1700.

KifleTesfamariam (2015b). Savings and Credit Cooperatives in Ethiopia: Development and Challenges: Journal of Economics and Sustainable Development, Vol.6, No.5 (2015), pp. 140-146, retrieved from, www.iiste.org. ISSN 2222-1700.

Kodama, Y. (2007). New Role of Cooperatives in Ethiopia: The Case of Ethiopian Coffee Farmers Cooperatives, African Study Monographs: Instituteof Developing Economies, JETRO, Suppl.35: pp. 87-108,

Laidlaw, A. (1974). The Cooperative Sector, Columbia: University of Missouri, USA, $\mathrm{pp}^{6-8}$.

McCarthy (2001)."The History of Agricultural Cooperatives" in Cooperative Business Today. First Quarter Vol.1, Issue 1 (2001), VOCA- Addis Ababa, Ethiopia.

Mohammed N, Lee BW (2015). Role of Cooperatives in Rural Development, the case of South Nations Nationalities and People Region, Ethiopia. Science Journal of Business and Management 3(4):102-108.

Mojo, D., C. Fischer, T. Degefa (2015b). "Social and Environmental Impacts of Agricultural Cooperatives: Evidence from Ethiopia": International Journal of Sustainable Development and World Ecology, 22(5): pp. 388-400.

Mojo, D., C. Fischer, T. Degefa (2017). The Development of Agricultural Cooperatives in Ethiopia: History and a Framework for Future Trajectory: Research Gate, EJOSSAH Vol. XIII, No.1, pp.50-77,DOI: 10.4314/ejossah.v13i1.3.

Nakkiran, S. (2002). A Treatise on Cooperative Management, Head PG Department of Cooperation TBML College, Fourth edition: Rainbow publications, India-Delhi,pp. 1- 593.

Oqubay, A. (2018). Industrial Policy and Late Industrialization in Ethiopia: Working Paper Series, African Development Bank, No. 303, pp.1-26, Abidjan, Côte d'Ivoire.

Ramachandran, R. \& Srinivasan, R. (2010). Financial Management, Sriram Publications, 1-G kalyanapurm, Tennur, Trichy-17.

Ruhul AM, Mohammed UM (2014). Socio-Economic Impacts of Cooperative Societies: An Empirical Study. SOCRATES: An International, Multi-lingual, Multi-disciplinary, Refereed (peer reviewed). Indexed Scholarly Journal 2(2):179-193.

Schwettmann (ILO COOP) (1994). Cooperatives and Employment in Africa: Final Report of the Regional Advisor on Cooperatives for Eastern, Southern and Central Africa (October 1988 to March 1994): ILO Cooperative Branch: Occasional Discussion Paper 97 - 1, Geneva.

Shaffer, J. (1999). Historical Dictionary of the Cooperative Movement. London UK: The Scarecrow Press.

Wendy Laura Belcher (2009). Writing your Journal Article in 12 Weeks: A Guide to Academic Publishing Success, USA, SAGE Publications, ISBN: 978-1-4129-5701-4.

WorkuTessema (2000). Stakeholder Participation in Policy Processes in Ethiopia, Managing Africa's Soils No. 17, IIED publications, London.

United Nations Framework Convention on Climate Change (UNFCCC) (2014, January 23). An Integrated Environmental Treaty, Retrieved from: http://unfccc.int/2860.php.

United Nation (2002). Investment and Innovation Policy Review in Ethiopia, United Nations Conference on Trade and Development: United Nations Publication, Geneva, pp.1-138.

Yoseph Derese (2014). Government Support Interventions and Autonomy of Agricultural Cooperatives in Ethiopia: The Case of Selected Regions, MA Thesis, Addis Ababa University. 